\title{
PHENOMENOLOGICAL MODEL OF UREA WATER SOLUTION DOSAGE STRATEGY FOR UREA-SELECTIVE CATALYTIC REDUCTION SYSTEMS
}

\author{
Sadashiva Prabhu S. ${ }^{1} \bowtie$, Nagaraj S. Nayak ${ }^{2}$ and Kapilan Natesan ${ }^{3}$ \\ ${ }^{1}$ Department of Mechanical and Manufacturing Engineering, Manipal Institute of Technology, \\ Manipal Academy of Higher Education, Manipal, Karnataka, India-576104 \\ ${ }^{2}$ KBAT Technologies Private Limited, Pune, Maharashtra, India-411033 \\ ${ }^{3}$ Department of Mechanical Engineering, Nitte Meenakshi Institute of Technology, \\ P.B.No.6429, Yelahanka, Bangalore-560064 \\ ${ }^{\circledR}$ Corresponding Author: ss.prabhu97@gmail.com
}

\begin{abstract}
Selective Catalytic Reduction (SCR) is the latest technology adopted to diesel engines of automobiles to transform $\mathrm{NO}_{x}$. The required reducing agent $\left(\mathrm{NH}_{3}\right)$ is generated after engine exhaust by injecting Urea in the form of Urea Water Solution (UWS). There are some numerical methods with limited experimental details to estimate the behavior of UWS droplets in a heated environment, and some of them have been implemented into CFD codes. In the CFD codes, many numerical relationships are not validated for the evaporation of UWS droplets. In the SCR system of modern automobiles, the dosage strategy is based on DOE techniques. But, the theoretical method is required for UWS dosage during optimization of the SCR system. So, an integrated zero-dimensional model is required for dosage strategy during simulation studies so that exact dosage could be possible based on $\mathrm{NO}_{\mathrm{x}}$, flow rate, and temperature of exhaust gas to suit actual SCR situations. In the present work, a phenomenological model is developed based on theoretical correlations, experimental data generated by authors, and data from the literature.

Keywords: Phenomenological Modelling, UWS, SCR, Dosage, Evaporation, Catalyst.
\end{abstract}

RASĀYAN J. Chem., Vol. 14, No.4, 2021

\section{INTRODUCTION}

Oxides of nitrogen $\left(\mathrm{NO}_{\mathrm{x}}\right)$ emitted from the exhaust of diesel engines can be reduced by the after-treatment method, Selective Catalytic Reduction (SCR). In this technique, Urea is used to generate the reducing agent ammonia $\left(\mathrm{NH}_{3}\right)$ and $32.5 \%$ aqueous urea solution is injected in the form of an atomized spray to hot exhaust gases. The UWS transforms into solid Urea and water vapor. Solid Urea undergoes thermolysis and produces $\mathrm{NH}_{3}$ and Isocyanic acid (HNCO). $\mathrm{HNCO}$ further reacts with water vapor and gives $\mathrm{CO}_{2}$ and $\mathrm{NH}_{3} .{ }^{1}$ The reduction of $\mathrm{NO}_{\mathrm{x}}$ takes place over the catalyst through various favorable reactions. ${ }^{2,3} \mathrm{NH}_{3}$ slip to the environment to be avoided by the proper dosage of UWS. UWS conversion to $\mathrm{NH}_{3}$ depends on several factors like temperature of the exhaust gas, residence time, type of spray, the droplet size of UWS, etc. Accordingly, the dosage strategy of UWS is to be tuned based on the factors associated with it.

The theoretical demand of $\mathrm{NH}_{3}$ was proposed by Calatayud et al. and Ciardell et al. ${ }^{4,5}$ Subsequently, the UWS requirement was proposed by Tao et al. ${ }^{6}$ In the numerical model proposed by Lu et al., engine speed, torque and temperature-related signals are sent to Dosing Control Unit through CAN-bus ${ }^{7}$ and required dosing is achieved. Once the SCR system is implemented in a diesel engine, the developed dosing control unit should be calibrated using DOE or with an emission map.

The SCR system has to work on varying engine load conditions, wherein temperature, the flow rate of exhaust gas, and $\mathrm{NO}_{\mathrm{x}}$ contents vary. The required UWS dosage has to be optimized based on $\mathrm{NO}_{\mathrm{x}}$ content and UWS decomposition characteristics. The stoichiometric urea requirements are calculated using chemical reactions which occur over the catalyst. The amount of $\mathrm{NO}_{\mathrm{x}}$ conversion is based on the conversion efficiency of a particular catalyst. The probability of reactions occurring over the catalyst is related to

Rasayan J. Chem., 14(4), 2486-2498(2021)

http://dx.doi.org/10.31788/RJC.2021.1446427

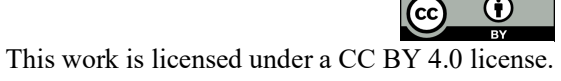


$\mathrm{NO}_{2} / \mathrm{NO}_{\mathrm{x}}$ ratio. Based on the efficiency of $\mathrm{NO}_{\mathrm{x}}$ reduction over SCR catalyst, reducing agent $\mathrm{NH}_{3}$ is calculated, and UWS dosing strategy is determined initially. However, when UWS is spray introduced into hot exhaust gases, vaporization of water from the droplet and subsequent urea decomposition plays a major role in the generation of $\mathrm{NH}_{3}$. When UWS droplet diameter is larger, the amount of evaporation reduces, and consequently, urea conversion reduces; thereby, the $\mathrm{NH}_{3}$ mass fraction drops down. The droplet evaporation and urea decomposition both vary with temperature and residence time. So, the stoichiometric quantity of $\mathrm{NH}_{3}$ generation from UWS cannot be attained at all conditions of exhaust gas. Therefore, the UWS requirement varies once again. So, the actual dosage strategy depends on the conversion efficiency at the catalyst, urea decomposition efficiency and percentage of evaporation UWS, etc. Some expressions found in the literature are not dealt with the evaporation of UWS and Urea conversion efficiencies. Further, many theoretical aspects were not incorporated in detail in them. In the present study of dosage modeling, major catalytic reactions based on $\mathrm{NO}_{\mathrm{x}} / \mathrm{NH}_{3}$ ratio, UWS droplet evaporation and Urea conversion efficiencies are considered. A classical model which contributes to predicting the dosage strategy is given in the following sections in detail.

\section{UWS Dosage Modelling}

UWS dosage modeling is accomplished in stages, namely, identifying catalytic reactions, generation of $\mathrm{NH}_{3}$ from UWS, determination of evaporation efficiency through the evaporation model and thermal decomposition of urea decomposition. Each stage is dealt with separately following sections. A few of the assumptions made while arriving at required expressions are i) UWS droplets are spherical, uniform size and, completely mix with hot air and do not settle iii) Solid urea decomposition after the evaporation of water from UWS iii) Catalytic reactions based on $\mathrm{NO}_{2} / \mathrm{NO}_{\mathrm{x}}$ ratio iv) Evaporation efficiency is based on global evaporation history.

\section{Catalytic Reactions}

The reduction of $\mathrm{NO}_{\mathrm{x}}$ is based on several catalytic reactions, and the occurrence of those reactions is based on $\mathrm{NO}_{2} / \mathrm{NH}_{\mathrm{x}}$ ratio. The major reactions that occur over the catalyst during the conversion of $\mathrm{NO}_{\mathrm{x}}$ into $\mathrm{N}_{2}$ are as follows. ${ }^{2,8}$

$2 \mathrm{NH}_{3}+\mathrm{NO}+\mathrm{NO}_{2} \rightarrow 2 \mathrm{~N}_{2}+3 \mathrm{H}_{2} \mathrm{O}$ (fast $S C R$ reaction)

$4 \mathrm{NH}_{3}+4 \mathrm{NO}+\mathrm{O}_{2} \rightarrow 4 \mathrm{~N}_{2}+6 \mathrm{H}_{2} \mathrm{O}$ (standard $S C R$ reaction)

$8 \mathrm{NH}_{3}+6 \mathrm{NO}_{2} \rightarrow 7 \mathrm{~N}_{2}+12 \mathrm{H}_{2} \mathrm{O}$ (slow $S C R$ reaction)

The subsequent $\mathrm{NH}_{3}$ requirement for the above reactions is based on the probability of occurrence of those reactions. Based on $\mathrm{NO}_{2} / \mathrm{NO}_{\mathrm{x}}$ ratio, the possible reactions are given in the following cases, and the $\mathrm{NH}_{3}$ requirement is calculated accordingly based on the molar fraction of $\mathrm{NO}$ and $\mathrm{NO}_{2}$. The molecular weights of $\mathrm{NH}_{3}, \mathrm{NO}$, and $\mathrm{NO}_{2}$ are taken as 17, 30, and 46, respectively, for required calculations. The detailed calculations of $\mathrm{NH}_{3}$ requirement based on $\mathrm{NO}_{\mathrm{x}}$ in the exhaust for two different cases of $\mathrm{NO}_{2} / \mathrm{NO}_{\mathrm{x}}$ ratios are as detailed in Appendix-II.

\section{$\mathrm{NH}_{3}$ Generation from UWS}

As discussed earlier, UWS droplets evaporate in a heated environment, and the Urea decomposes into $\mathrm{NH}_{3}$ and $\mathrm{HNCO}$. HNCO undergoes hydrolysis and generates $\mathrm{NH}_{3}$. So, the actual $\mathrm{NH}_{3}$ generation is based on the efficiency of evaporation, efficiencies of thermolysis, and hydrolysis processes. Based on the factors involved in $\mathrm{NH}_{3}$ formation from UWS spray, the $\mathrm{NH}_{3}$ generated can be expressed as a function of stage efficiencies of evaporation, thermolysis, and hydrolysis. A simple $\mathrm{NH}_{3}$ conversion factor comprising these efficiencies is multiplied by stoichiometric $\mathrm{NH}_{3}$ to find actual $\mathrm{NH}_{3}$. So, it is written in the form,

Actual $\mathrm{NH}_{3}$ generated=Stoichiometric $\mathrm{NH}_{3} \times \mathrm{NH}_{3}$ Conversion Factor

$\mathrm{NH}_{3}$ Conversion Factor $=f$ (evaporation efficiency, thermolysis efficiency, hydrolysis efficiency) Usually, it is considered as:

$\mathrm{NH}_{3}$ Conversion Factor $=\left\{\eta_{\text {evap }} \times\left(\eta_{\text {therm }}+\eta_{\text {hyd }}\right)\right\}$ 
To determine UWS evaporation efficiency, the temperature, droplet size, and residence time are considered major variables and efficiency of urea decomposition can be evaluated using pre-determined rate equations. ${ }^{9}{ }^{10}$ Hydrolysis is a slow reaction that requires a catalyst if the residence time is less in SCR mixing pipe. The hydrolysis reaction is considered to occur by two pathways, namely catalytic and non-catalytic. Catalytic hydrolysis is considered with rate equation of hydrolysis reaction whereas non-catalytic hydrolysis by experimental methods relating to residence time. Each of the above efficiencies is calculated by respective mathematical models as described in the following sections. Accordingly, the $\mathrm{NH}_{3}$ conversion factor is calculated using the relation mentioned above.

\section{Determination of Efficiency of Evaporation ( $\left.\boldsymbol{\eta}_{\text {evap }}\right)$}

The residence time is an important parameter that relates to the efficiency of evaporation. It is the time required to fill the SCR mixing chamber with the incoming exhaust gas, and it is evaluated as $t_{r}=$ Volume of the SCR mixing chamber $\left(\mathrm{m}^{3}\right) /$ Volume flow rate of exhaust gas $\left(\mathrm{m}^{3} / \mathrm{sec}\right)$. The required residence time for evaporation of UWS droplets is based on their droplet sizes. Another important factor that determines the rate of evaporation and evaporation efficiency is the temperature of the exhaust gas. There are some additional factors like UWS flow rate, injection methods, heat transfer coefficient, etc. However, we consider the most influencing factors like residence time, temperature, and droplet size in our modeling. Modeling of both evaporation of water and urea thermolysis are explained in the following sections in detail.

\section{UWS Evaporation Model}

In this evaporation model, a spherical liquid droplet in a hot exhaust gas atmosphere is considered, which provides a convection environment to the droplet. The heat transfer due to convection leads to an increase in droplet temperature till its boiling point $\left(\mathrm{T}_{\mathrm{e}}\right)$, and drop temperature is considered to be constant afterward, and water evaporation is considered to initiate from this point. The mass flow rate from the droplet during the evaporation of the droplet is expressed in the following form considering energy balance during the evaporation process 9 .

$\mathrm{L} \frac{\mathrm{dm}_{\mathrm{d}}}{\mathrm{dt}}=-\phi_{\mathrm{c}}$

$\phi_{c}$ is the heat flux due to convection, $\mathrm{m}_{\mathrm{d}}-\mathrm{a}$ mass of the droplet and $\mathrm{L}$ is the latent heat of evaporation and convection heat transfer ' $h$ 'can be obtained through Nusselt number $(\mathrm{Nu})$ as,

$\mathrm{h}=\frac{\mathrm{Nu} \lambda_{\mathrm{g}}}{\mathrm{D}_{\mathrm{d}}}$, where $\lambda \mathrm{g}$ is the thermal conductivity of the gas, $\mathrm{D}_{\mathrm{d}-\text { droplet diameter. }}{ }^{9}$ Assuming the uniform temperature in the droplet and is equal to $\mathrm{T}_{\mathrm{e}}$. The convection heat flux $\phi_{\mathrm{c}}$ can be expressed as,

$\phi_{\mathrm{c}}=\pi \mathrm{D}_{\mathrm{d}}^{2} \frac{\mathrm{Nu} \lambda_{\mathrm{g}}}{\mathrm{D}_{\mathrm{d}}}\left(\mathrm{T}_{\mathrm{a}}-\mathrm{T}_{\mathrm{e}}\right)$

where $\mathrm{T}_{\mathrm{a}}$ is the temperature of surrounding gas, assuming uniform temperature throughout the droplet and equal to $\mathrm{T}_{\mathrm{e}}{ }^{9}$. The linear form of evolution of droplet size is given by $\mathrm{D}^{2}$-law,

$D_{d}^{2}(t)=-\beta_{e} t+D_{d}^{0^{2}}$

$\mathrm{D}_{\mathrm{d}}^{0}=$ initial drop diameter $\mathrm{D}_{\mathrm{d}}(\mathrm{t})$-drop diameter after time interval ' $\mathrm{t}$ ', $\beta_{\mathrm{e}}$-evaporation rate which is obtained as,

$\beta_{\mathrm{e}}=\frac{4 \lambda \mathrm{g}}{\mathrm{L} \rho_{\mathrm{W}}} \mathrm{Nu}\left(\mathrm{T}_{\mathrm{a}}-\mathrm{T}_{\mathrm{e}}\right)$

Birkhold et al. ${ }^{10}$ used Nusselt number to evaluate UWS drop evaporation in the following form.

$\mathrm{Nu}=\frac{\ln \left(1+\mathrm{B}_{\mathrm{T}}\right)}{\mathrm{B}_{\mathrm{T}}} \mathrm{Nu}_{0}$ where $\mathrm{B}_{\mathrm{T}}=\frac{\mathrm{c}_{\mathrm{p}, \text { vap }}\left(\mathrm{T}_{\mathrm{a}}-\mathrm{T}_{\mathrm{e}}\right)}{\mathrm{L}}$ where $\mathrm{B}_{\mathrm{T}}$ is the Spalding Number related to heat transfer and $c_{p, v a p}$ is the vapor specific heat capacity. 
RASĀYAN J. Chem.

Vol. 14 | No. 4 |2486-2498| October- December | 2021

$\rho_{\mathrm{w}}$-liquid water density and Nusselt number $\left(\mathrm{Nu}_{0}\right)$ corresponds to droplet diameter, and relative velocity of the droplet in the hot gas is given by,

$\mathrm{Nu}_{0}=2.0+0.552 \mathrm{Re}_{\mathrm{d}}^{\frac{1}{2}} \operatorname{Pr}^{\frac{1}{3}}$

where Reynolds Number $\mathrm{Re}_{\mathrm{d}}$ is calculated based on droplet diameter and Prandtl number $\mathrm{Pr}$ is obtained based on the property of exhaust gas. ${ }^{9}$ The quantity $0.552 \operatorname{Re}_{\mathrm{d}}^{\frac{1}{2}} \operatorname{Pr}^{\frac{1}{3}}$ is added to consider turbulence aspects along with convection. In our modeling, the expression containing the Nusselt number is used for the evaporation rate from a droplet, and it can be expressed as,

$\beta_{\mathrm{e}}=\frac{4 \lambda_{\mathrm{G}}}{\rho_{\mathrm{w}} \mathrm{c}_{\mathrm{p}, \text { vap }}} \ln \left(1+\mathrm{B}_{\mathrm{T}}\right) \mathrm{Nu}_{0}$

The density of UWS is given by $\rho_{\mathrm{UWS}}=\left(1-\mathrm{C}_{\mathrm{u}}\right) \rho_{\mathrm{w}}+\mathrm{C}_{\mathrm{u}} \rho_{\mathrm{u}}$

The diameter of the droplet ' $\mathrm{D}_{d}$ ' after complete evaporation of water after time interval ' $t_{e}$ ' is evaluated using the relation,

$\rho_{\mathrm{u}} \frac{\pi \mathrm{D}_{\mathrm{d}}^{3}}{6}=\mathrm{C}_{\mathrm{u}} \rho_{\mathrm{UWS}} \frac{\pi \mathrm{D}_{0}^{3}}{6}$ along with the equation of $\rho_{\mathrm{UWS}}$

and Eq.-7 results,

$D_{d}^{2}(t)=\left(C_{u}\left(C_{u}+\left(1-C_{u}\right) \frac{\rho_{w}}{\rho_{u}}\right)\right)^{\frac{2}{3}} D_{o}^{2}$

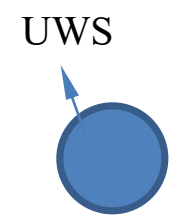

$D_{d}$

The time of evaporation ' $\mathrm{t}_{\mathrm{e}}$ ' can be evaluated as,

$\mathrm{t}_{\mathrm{e}}=\left\{1-\left(\mathrm{C}_{\mathrm{u}}\left(\mathrm{C}_{\mathrm{u}}+\left(1-\mathrm{C}_{\mathrm{u}}\right) \frac{\rho_{\mathrm{w}}}{\rho_{\mathrm{u}}}\right)\right)^{\frac{2}{3}}\right\} \frac{\mathrm{D}_{\mathrm{o}}^{2}}{\beta_{\mathrm{e}}}=\frac{1}{\beta_{\mathrm{e}}} 0.58 \mathrm{D}_{0}^{2}$

In SCR mixing pipe, the rate of flow for which $t_{r}>t_{e}$ the evaporation efficiency is considered as $100 \%$. For the case, $\mathrm{t}_{\mathrm{r}}<\mathrm{t}_{\mathrm{e}}$ the evaporation efficiency is to be determined as,

$$
\eta_{\text {evp }}=\frac{\frac{4}{3} \pi\left\{\frac{D_{0}^{3}}{8}-\frac{\left(D_{0}^{2}-\beta t_{r}\right)^{\frac{3}{2}}}{8}\right\} \rho_{\text {uws }} \times 100}{\frac{4}{3} \pi\left\{\frac{D_{0}^{3}}{8}\right\} \rho_{\text {uws }}}=\frac{D_{0}^{3}-\left(D_{0}^{2}-\beta t_{r}\right)^{\frac{3}{2}} \times 100}{D_{0}^{3}}
$$

\section{EXPERIMENTAL}

For validation, evaporation efficiency obtained numerically from the Eq.-13 is done from the experiments conducted in a hot air test bench for different flow rates at a fixed rate of UWS injection. Instead of single droplet evaporation, the global evaporation history of a spray of UWS is considered. In the hot air test bench, droplets are made to pass over metal foil (circular shape), as shown in Fig.-1a. The UWS droplets which are not evaporated and decomposed are collected in the metal foil. The amount of UWS injection for a particular duration $(4 \mathrm{sec})$ is taken as $\mathrm{W}_{0}$. The initial weight of the film is taken as $\mathrm{W}_{1} \mathrm{gms}$, and the weight of the foil after 4 seconds of the collection is taken as $\mathrm{W}_{2}$ gms. The difference of weights $\left(\mathrm{W}_{2}-\mathrm{W}_{1}\right)$ accounts for the weight of water not evaporated plus the weight of undecomposed Urea. The film is made to dry in the open air, and the weight is measured again as $\mathrm{W}_{3}$. All $\mathrm{W}_{1}, \mathrm{~W}_{2}$, and $\mathrm{W}_{3}$ are obtained from the digital weighing machine with accuracy $\pm 10 \mathrm{mg}$. Now the weight difference of weights $\left(\mathrm{W}_{2}-\mathrm{W}_{3}\right)$ accounts for the amount of water evaporated from foil. In other words, the quantity $\left(\mathrm{W}_{2}-\mathrm{W}_{3}\right)$ is the amount of water which not evaporated from the original UWS quantity $\mathrm{W}_{0}$. This quantity is measured for a fixed rate of injection of UWS $10 \mathrm{ml} / \mathrm{min}$, and the water content in the injected quantity of UWS is equal to $0.833 \mathrm{gms}\left(\mathrm{m}_{0}=\right.$ flow 
rate of UWS $\times$ water mass fraction $\left(Y_{\text {water }}\right)$ in UWS $(0.675) \times$ duration of injection (4 seconds)). The percentage of evaporation is evaluated as,

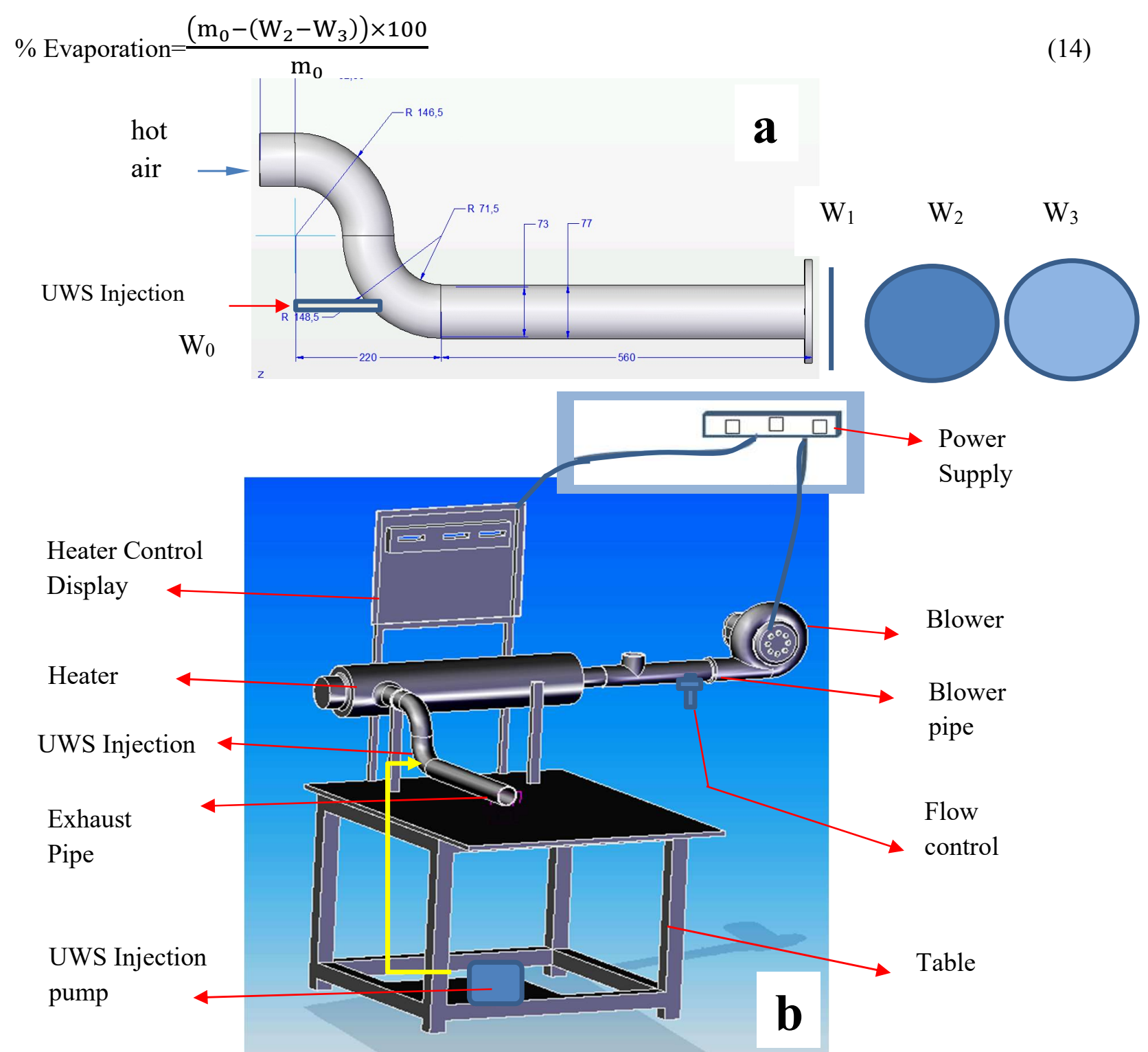

Fig.-1: (a) Exhaust Pipe and Metal Foil, (b) Schematic Experimental Setup

\section{RESULTS AND DISCUSSION}

The results of experimental values from Eq.-14 for various flow conditions are compared with numerical results obtained from Eq.-13, and good agreement is observed at all temperatures, except with some deviation at $150^{\circ} \mathrm{C}$ (Fig.-2a to d). At $150^{\circ} \mathrm{C}$, experimental values were found superior to numerical values. The experimental values do not account for the weight of UWS droplets that settle by gravity and adhere to walls of the pipe which are of significant quantities at $150^{\circ} \mathrm{C}$. This leads to a decrease in quantity $\mathrm{W}_{2}-$ $\mathrm{W}_{3}$. So, the efficiency of evaporation shows a higher value as per Eq.-14. As numerical values are based on evaporation and decomposition of single droplets wherein gravity effects and wall effects are ignored.

Note: If the residence time $\mathrm{t}_{\mathrm{r}}>\mathrm{t}_{\mathrm{e}}$ evaporation of UWS is complete, the percentage of evaporation is assumed to be $100 \%$. However, for shorter residence times, the evaporation amount is calculated based on mass corresponding to the volume difference of the droplet. The final volume is obtained based on the diameter, which is calculated using $\mathrm{D}^{2}$-law. 
RASĀYAN J. Chem.

Vol. 14 | No. 4 |2486-2498| October- December | 2021
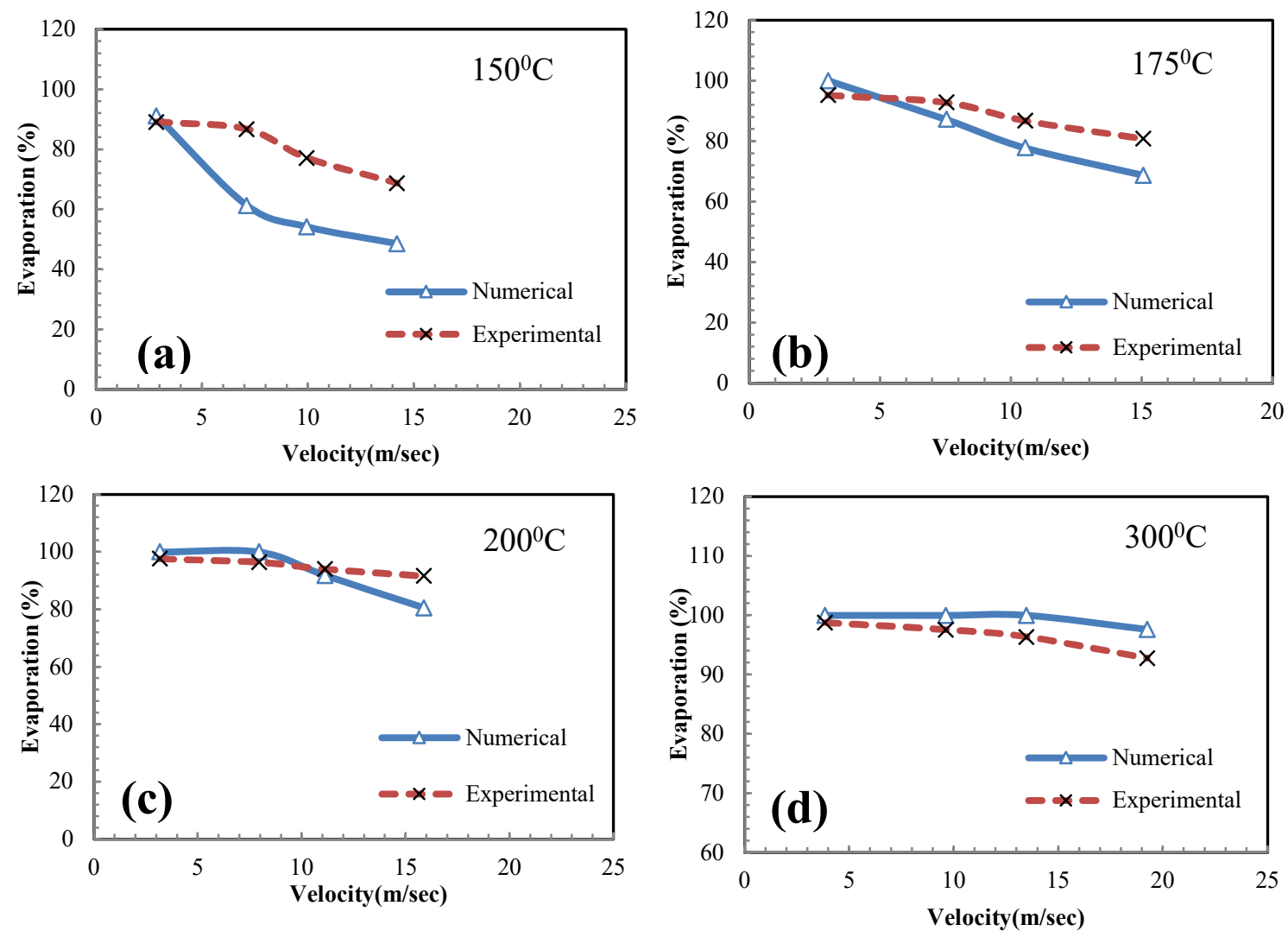

Fig.-2: Comparison of Experimental and Numerical Percentage of Evaporation at (a) $150^{\circ} \mathrm{C}$ (b) $175^{\circ} \mathrm{C}$ (c) $200^{\circ} \mathrm{C}$ and

Thermal Decomposition Efficiency of Urea

(d) $300^{\circ} \mathrm{C}$

Thermal decomposition of Urea takes place by heat addition from the hot exhaust gas. The rate constant in the exponential form can be obtained as:

$$
k=\mathrm{Ae}^{-\frac{\mathrm{E}_{\mathrm{a}}}{\mathrm{RT}}}
$$

Where $k$ is the rate constant, $\mathrm{E}_{\mathrm{a}}$ is the activation energy, $\mathrm{A}$ is the frequency factor, $\mathrm{R}$ is the gas constant, and $\mathrm{T}$ is the temperature. As mentioned earlier, $\mathrm{NH}_{3}$ formation from urea decomposition follows two steps,

(i) Decomposition urea (Thermolysis) into $\mathrm{NH}_{3}$ and $\mathrm{HNCO}$ occurs by the reaction,

$\left(\mathrm{NH}_{2}\right)_{2} \mathrm{CO}_{(\mathrm{l})} \longrightarrow \mathrm{NH}_{3(\mathrm{~g})}+\mathrm{HNCO}_{(\mathrm{g})}$

(ii)Conversion of isocyanic acid into $\mathrm{NH}_{3}$ (Hydrolysis of $\mathrm{HNCO}$ ) occurs by the reaction,

$\mathrm{HNCO}\left(\mathrm{g}+\mathrm{H}_{2} \mathrm{O} \longrightarrow \mathrm{NH}_{3(\mathrm{~g})}+\mathrm{CO}_{2(\mathrm{~g})}\right.$

In the following section, the urea thermolysis process and efficiency of urea thermolysis in a hot gas environment are discussed.

\section{Estimation of urea thermolysis efficiency}

We consider a fast reaction for the conversion of gaseous Urea to $\mathrm{NH}_{3}$ and $\mathrm{HNCO}$, which is proposed by Rota et al. ${ }^{11}$, for which rate constant is in the form,

$$
\mathrm{k}=\mathrm{A}\left[\frac{\mathrm{T}}{\mathrm{T}_{0}}\right]^{\mathrm{n}} \mathrm{e}^{-\frac{\mathrm{E}_{\mathrm{a}}}{\mathrm{RT}}}
$$

Where A- is the frequency factor $12700 \mathrm{~s}^{-1}, \mathrm{E}_{\mathrm{a}}$-is the activation energy $(15540 \mathrm{~J} / \mathrm{mol})$, $\mathrm{T}$ - is the gas temperature, $T_{0^{-}}$is a reference temperature, and ' $\mathrm{n}$ ' is a dimensionless number often it is taken as zero. ${ }^{11 \text {, }}$ ${ }^{12}$ The rate of decomposition of Urea is given as, 
RASĀYAN J. Chem.

Vol. 14 | No. 4 |2486-2498| October- December | 2021

$\frac{\mathrm{dC}_{\mathrm{u}}}{\mathrm{dt}}=-\mathrm{kC}_{\mathrm{u}}$

Where $C_{u}$ is the urea concentration in $\mathrm{mol} / \mathrm{m}^{3}$ and ' $\mathrm{t}$ ' is time in seconds. The time available for urea decomposition can be estimated as the difference between residence time and evaporation time $\left(t_{r}-t_{e}\right.$. ). For the evaluation of the amount of urea decomposition, the Eq. (19) is rearranged and integrated as below for concentration limits $\mathrm{C}_{1}$ to $\mathrm{C}_{2}$ and time limits 0 to $\left(\mathrm{t}_{\mathrm{r}}-\mathrm{t}_{\mathrm{e}}\right)$.

$\int_{c_{1}}^{c_{2}} \frac{\mathrm{dC}_{\mathrm{u}}}{\mathrm{C}_{\mathrm{u}}}=-\mathrm{k} \int_{0}^{\mathrm{t}_{\mathrm{r}}-\mathrm{t}_{\mathrm{e}}} \mathrm{dt} \Rightarrow \log \left[\mathrm{C}_{2}\right]-\log \left[\mathrm{C}_{1}\right]=-\mathrm{k}\left(\mathrm{t}_{\mathrm{r}}-\mathrm{t}_{\mathrm{e}}\right) \Rightarrow \frac{\mathrm{C}_{2}}{\mathrm{C}_{1}}=\mathrm{e}^{-\mathrm{k}\left(\mathrm{t}_{\mathrm{r}}-\mathrm{t}_{\mathrm{e}}\right)}$

Then the thermolysis efficiency reduces to a form,

$\eta_{\text {the }}=\frac{\mathrm{C}_{1}-\mathrm{C}_{2}}{\mathrm{C}_{1}}=1-\mathrm{e}^{-\mathrm{k}\left(\mathrm{t}_{\mathrm{r}}-\mathrm{t}_{\mathrm{e}}\right)}$

Note: The $C_{1}$ and $C_{2}$ can be in any units in Eq.20.We assume thermolysis efficiency as $99 \%$ to determine the minimum time required for thermolysis.

$\frac{\mathrm{C}_{1}-\mathrm{C}_{2}}{\mathrm{C}_{1}}=1-\mathrm{e}^{-\mathrm{kt}}$ ther $=0.99 \Rightarrow 0.01=\mathrm{e}^{-\mathrm{kt}}$ ther $\quad$ where $\mathrm{t}_{\text {ther }}=$ thermolysis time

If $t_{r}-t_{e}>t_{t h e r}$, then it infers that urea thermolysis is $100 \%$ and if $t_{r}-t_{e}<t_{t h e r}$, then the percentage of thermolysis is calculated using Eq.-20.

\section{Conversion of Isocyanic acid into $\mathrm{NH}_{3}$ (Hydrolysis Reaction) \\ Catalytic Conversion}

$\mathrm{HNCO}$, which is formed during the thermolysis process, will undergo hydrolysis and gives $\mathrm{NH}_{3}$. The hydrolysis of Isocyanic acid is a slower reaction compared to thermolysis. Usually, it occurs over the catalyst. However, it occurs with higher residence time and at elevated temperatures of the exhaust gas without the catalyst. The rate of reaction over the catalyst for the hydrolysis reaction is given by the following formula ${ }^{3}$,

$$
\begin{aligned}
& \frac{\mathrm{dC}_{\mathrm{HNCO}}}{\mathrm{dt}}=\mathrm{C}_{\mathrm{HNCO}} \times 2.5 \times 10^{5} \mathrm{e}^{-\frac{-62220}{\mathrm{RT}}} \\
& \frac{\mathrm{dC}_{\mathrm{HNCO}}}{\mathrm{C}_{\mathrm{HNCO}}}=2.5 \times 10^{5} \mathrm{e}^{\frac{-62220}{\mathrm{RT}}} \mathrm{dt} \quad=\mathrm{kt} \text { if } \mathrm{k}=2.5 \times 10^{5} \mathrm{e}^{\frac{-62220}{\mathrm{RT}}}
\end{aligned}
$$

Where C-molar concentration in $\mathrm{mol} / \mathrm{m}^{3}$, R-universal gas constant in $\mathrm{J} / \mathrm{mol} \mathrm{K}$. T-temperature in $\mathrm{K}$ and $\mathrm{t}$ is time in secs. It is assumed that hydrolysis reaction occurs in the time interval after evaporation and thermolysis times have been elapsed. So, integrate for the limits $C_{1}$ to $C_{2}$ for HNCO and 0 to $t_{r}-\left(t_{e}+t_{\text {ther }}\right)$ for' $\mathrm{t}^{\prime}$, and we get the final expression as given below:

$\eta_{\text {hyd }}=\frac{\mathrm{C}_{1}-\mathrm{C}_{2}}{\mathrm{C}_{1}}=1-\mathrm{e}^{-\mathrm{k}\left(\mathrm{t}_{\mathrm{r}}-\left(\mathrm{t}_{\mathrm{e}}+\mathrm{t}_{\text {ther }}\right)\right)}$

Note: The above method of determination of conversion efficiency is valid if the hydrolysis takes place over the catalyst.

\section{Non-Catalytic Conversion of Isocyanic acid into $\mathrm{NH}_{3}$ (Hydrolysis Reaction)}

Here, unlike the previous method, the $\mathrm{NH}_{3}$ is generated by hydrolysis at elevated temperatures and increased residence time. The experimental results of Kim et al. ${ }^{13}$ which have been used by few authors to compare their simulated resluts ${ }^{10,14}$. Same results are used here to obtain the rate of hydrolysis in which no catalyst is used and authors opine experimental values obtained are due to both thermolysis and hydrolysis reactions. From the plots of conversion efficiency vs. residence time (Figs.-3a to c, Fig.-4 a to e), the conversion efficiency $(\eta)$ can be expressed in the form of a straight-line equation, $\eta=C_{1} t+C_{2}$ by curve fitting. 


\section{RASĀYAN J. Chem.}

Vol. 14 | No. 4 |2486-2498| October- December | 2021

The conversion efficiency is equal to $\mathrm{C}_{2}$ when $\mathrm{t}=0$. As the thermolysis reaction is very fast, the time required for thermolysis is very small. In such cases, when $t_{\text {ther }} \sim 0$, the constant $C_{2}$ can be considered as $\eta_{\text {ther, }}$, and the remaining part of the equation can be considered as $\eta_{\text {hyd }}=\mathrm{C}_{1} t$. For the SCR system with residence $t_{r}$, the time available for hydrolysis is $t_{r}-\left(t_{\text {ther }}+t_{e}\right)$, and it can be substituted in place of ' $t$ '. Then the efficiency of hydrolysis is expressed as, $\eta_{\text {hyd }}=\mathrm{C}_{1}\left[\mathrm{t}_{\mathrm{r}}-\left(\mathrm{t}_{\text {ther }}+\mathrm{t}_{\mathrm{e}}\right)\right]$.
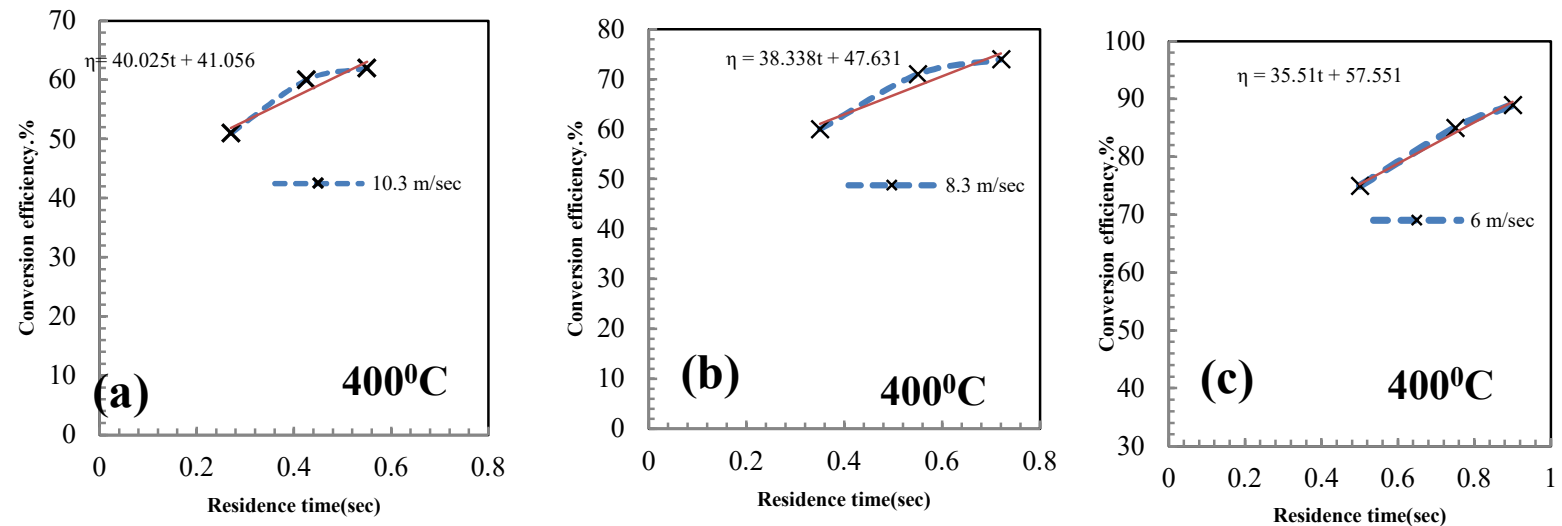

Fig.-3:Conversion Efficiency of Urea at Different Flow Rates and at Temperature of $400^{\circ} \mathrm{C}$ with respect to Residence Time at (a) $10.3 \mathrm{~m} / \mathrm{sec}$ (b) $8.3 \mathrm{~m} / \mathrm{sec}$ and (c) $6 \mathrm{~m} / \mathrm{sec}^{10,13,14}$
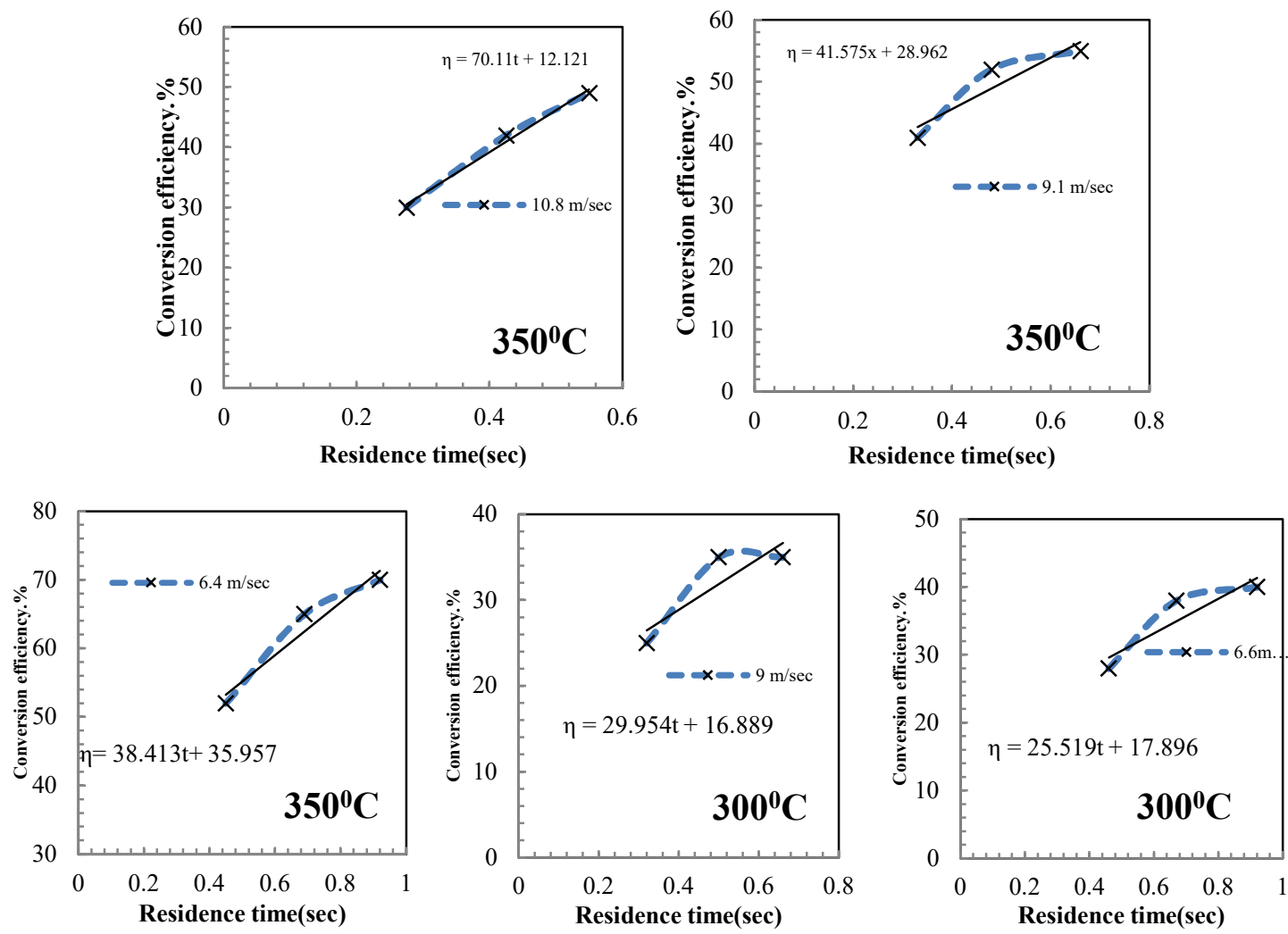

Fig.-4: Conversion Efficiency of Urea at Different Flow Rates and Temperature with respect to Residence Time for conditions (a) $350^{\circ} \mathrm{C}-10.8 \mathrm{~m} / \mathrm{sec}$ (b) $350^{\circ} \mathrm{C}-9.1 \mathrm{~m} / \mathrm{sec}$ (c) $350^{\circ} \mathrm{C}-6.4 \mathrm{~m} / \mathrm{sec}$ (d) $300^{\circ} \mathrm{C}-9 \mathrm{~m} / \mathrm{sec}$ and (e) $300^{\circ} \mathrm{C}-6.6$ $\mathrm{m} / \mathrm{sec}^{10,13,14}$

\section{Evaluation of Constant $\mathbf{C}_{1}$}

Assuming there is no hydrolysis catalyst in SCR mixing pipe, $\mathrm{C}_{1}$ is evaluated using experimental data obtained from Kim et al. ${ }^{13}$. In any SCR system, evaporation and thermolysis both occur in a very short time for the droplet sizes ranging from $20-200 \mu \mathrm{m}$. The first stage of urea decomposition (thermolysis) gives nearly $30-50 \%$ of total $\mathrm{NH}_{3}$. The obtained from experiments of Kim et al. indicate conversion efficiency for residence times up to $0.8 \mathrm{sec}$ for all temperature ranges ${ }^{13}$. As thermolysis time is very short, the variation 
RASĀYAN J.Chem.

Vol. 14 | No. 4 |2486-2498| October- December | 2021

of conversion efficiency after $0.1 \mathrm{sec}$ is only due to the hydrolysis effect. Hence, the variation of the $\mathrm{NH}_{3}$ concentration after 0.1 secs indicates the variation of conversion efficiency due to hydrolysis alone. The nature of graphs of experimental data is linear in the form $\eta=C_{1} t+C_{2}$. With appropriate curve fitting, the constant $\mathrm{C}_{1}$ is approximated as $35-45$ depending on the temperature range.

\section{UWS Dosage Calculation}

We know that, Actual $\mathrm{NH}_{3}$ generated=Stoichiometric $\mathrm{NH}_{3} \times \mathrm{NH}_{3}$ conversion factor

Stoichiometric $\mathrm{NH}_{3}=\frac{34}{60} \times 0.325 \times \mathrm{m}_{\text {uws }}$

(Eq.-3. of Appendix)

$\left(\mathrm{NH}_{3}\right)$ conversion factor $=\eta_{\text {evap }} \times\left(\eta_{\text {therm }}+\eta_{\text {hyd }}\right)$

Actual $\mathrm{NH}_{3}$ generated from UWS $=\mathrm{NH}_{3}$ generated (stoichiometric) $\times\left(\mathrm{NH}_{3}\right)$ conversion factor

$\Rightarrow$ Actual $\mathrm{NH}_{3}$ generated from UWS $=$ Stoichiometric $\mathrm{NH}_{3} \times\left(\eta_{\text {evap }} \times\left(\eta_{\text {ther }} \eta_{\text {hyd }}\right)\right)$

We can conclude that $\mathrm{NH}_{3}$ required for catalytic conversion of $\mathrm{NO}_{\mathrm{x}}$ should be equal to $\mathrm{NH}_{3}$ generated from UWS, and in such cases, Eq. (4) and Eq. (23) can be equated and it can be written as,

Actual $\mathrm{NH}_{3}$ required for reduction of $\mathrm{NO}_{\mathrm{x}}=$ Actual $\mathrm{NH}_{3}$ generated from UWS

$$
\begin{gathered}
\Rightarrow \mathrm{K} \frac{17 \times[\mathrm{X}] \times \mathrm{M}_{\text {ex }} \times 1000}{29 \times 3600}=\left(\mathrm{NH}_{3}\right) \text { generated } \\
\Rightarrow \mathrm{K} \text { (stoichiometric) } \\
\begin{array}{c}
29 \times[\mathrm{X}] \times \mathrm{M}_{\text {ex }} \times 1000 \\
29 \times 3600
\end{array}=\frac{34}{60} \times 0.325 \times \mathrm{m}_{\text {uws }} \times\left(\eta_{\text {evap }} \times\left(\eta_{\text {ther }}+\eta_{\text {hyd }}\right)\right) \\
\text { where (i) } \mathrm{K}=1 \text { if } \mathrm{x}=\mathrm{NO}_{2} / \mathrm{NO}_{\mathrm{x}}<0.5 \text { (ii) } \mathrm{K}=\left\{\frac{2}{3}+\frac{2}{3} \mathrm{x}\right\} \text { if } \mathrm{x}=\mathrm{NO}_{2} / \mathrm{NO}_{\mathrm{x}}>0.5
\end{gathered}
$$

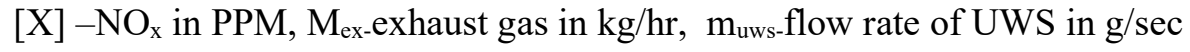

From the above equation, $\mathrm{m}_{\mathrm{uws}}$ is calculated as a function of $\mathrm{NO}_{\mathrm{x}}$ and mass flow rate. The effect of temperature, residence time, and droplet size are accounted in terms like $\eta_{\text {evap }}, \eta_{\text {ther, }}$ and $\eta_{\text {hyd. }}$.

As a summary, the expression obtained in Eq.-24 gives a complete dosage strategy considering many variables such as the mass of the exhaust gases, $\mathrm{NO}_{\mathrm{x}}$ content, the efficiency of evaporation, thermolysis and hydrolysis efficiencies. The numerical results of evaporation of UWS droplets were found in-line with experimental values. Numerical methods are followed for thermolysis of Urea and hydrolysis of HNCO over catalyst. Further non-catalytic conversion of Urea was also considered.

\section{CONCLUSION}

In the phenomenological model developed, the UWS dosage strategy is based on variables like temperature, residence time, droplet diameter, amount of $\mathrm{NO}_{\mathrm{x}}$ present, and the mass flow rate of exhaust gas. To establish by classical or other methods $\mathrm{NH}_{3}$ requirement based on $\mathrm{NO}_{\mathrm{x}}$ content, exhaust temperature, and flow rate so that the reducing agent is correctly dosed in the simulation for parametric studies. The model includes stage efficiencies of evaporation, urea decomposition, and catalytic conversion. The model enables us to do a UWS dosage strategy for simulation studies of SCR systems based on the above variables, and the same can be utilized for actual transient engine cycles as a complementary approach to other conventional DOE methods. Among dosage modeling obtained in literature, many theoretical aspects especially evaporation and thermolysis based on residence, are not incorporated in detail. Some numerical code developed can provide $\mathrm{NH}_{3}$ distribution and conversion efficiency for a particular case. The developed phenomenological model accounts for many theoretical aspects related to evaporation and urea decomposition in addition. Further, for transient load conditions with varying flow rates and $\mathrm{NO}_{\mathrm{x}}$ in realtime scenarios, the developed model can be used to get a dosage of UWS accurately.

\section{ACKNOWLEDGEMENT}

The authors would like to thank the Manipal Institute of Technology Manipal for their support in writing this paper. 
Thermolysis of Urea

\section{APPENDIX-I}

$\left(\mathrm{NH}_{2}\right)_{2} \mathrm{CO}_{(\mathrm{l})} \rightarrow \mathrm{NH}_{3(\mathrm{~g})}+\mathrm{HNCO}_{(\mathrm{g})}$

Writing molecular weights,

$60 \quad 17 \quad 43$

For 1 mole of Urea

$1 \quad 17 / 60 \quad 43 / 60$

Then, Isocyanic acid may hydrolyze to give $\mathrm{NH}_{3}$ and $\mathrm{CO}_{2}$

$\mathrm{HNCQ}_{\mathrm{g})}+\mathrm{H}_{2} \mathrm{O} \rightarrow \mathrm{CO}_{2(\mathrm{~g})}+\mathrm{NH}_{3(\mathrm{~g})}$

Writing molecular weights

$\begin{array}{llll}43 & 18 & 44 & 17\end{array}$

For 1 mole

$1 \quad 18 / 43 \quad 44 / 43 \quad 17 / 43$

If $43 / 60$ mole of $\mathrm{HNCO}$ is available, then

$43 / 60 \quad 17 / 43 \times 43 / 60=17 / 60$ mole

Total $\mathrm{NH}_{3}$ by both thermolysis and hydrolysis $=17 / 60+17 / 60=34 / 60$ mole

Flow rate of $\mathrm{NO}_{\mathrm{x}}(\mathrm{kg} / \mathrm{sec})=$ Mass flow rate exhaust gas $\times$ mass fraction of $\mathrm{NO}_{\mathrm{x}}$ in exhaust gas

$\mathrm{M}_{\mathrm{NOx}}=\mathrm{M}_{\mathrm{exh}(\mathrm{kg} / \mathrm{hr})}$ (volume fraction of $\mathrm{NO}_{\mathrm{x}} \times$ Molecular wt. of $\left.\mathrm{NO}_{\mathrm{x}}\right) / \mathrm{Molecular}$ wt. of exhaust gas

$\begin{aligned} \mathrm{M}_{\mathrm{NOx}}= & \mathrm{M}_{\mathrm{ex}} \frac{[\mathrm{X}]\{(1-\mathrm{x}) 30+\mathrm{x} 46\}}{29} \mathrm{~kg} / \mathrm{hr} \text { of } \mathrm{NO}_{\mathrm{x}} \\ = & \mathrm{M}_{\mathrm{ex}} \frac{[\mathrm{X}]\{(1-\mathrm{x}) 30+\mathrm{x} 46\}}{29 \times 3600} \times 1000 \mathrm{gm} / \mathrm{sec} \text { of } \mathrm{NO}_{\mathrm{x}}\end{aligned}$

APPENDIX-II

\section{Case-1: $\mathrm{NO}_{2} / \mathrm{NO}_{\mathrm{x}}<0.5$}

If exhaust gas contains 1 mole of $\mathrm{NO}_{\mathrm{x}}$, then the fraction of $\mathrm{NO}_{2}$ is ' $\mathrm{x}$ ' mole, and the fraction of $\mathrm{NO}$ is ' $1-\mathrm{x}$ ' mole. Mathematically,

$\mathrm{NO}_{\mathrm{x}}=\mathrm{NO}+\mathrm{NO}_{2}=1, \mathrm{NO}_{2} / \mathrm{NO}_{\mathrm{x}}=\mathrm{x}, \mathrm{NO} / \mathrm{NO}_{\mathrm{x}}=1-\mathrm{x}$

If $\mathrm{NO}_{2}<\mathrm{NO}\left(\mathrm{NO}_{2} / \mathrm{NO}_{\mathrm{x}}<0.5\right)$, then it is assumed that $\mathrm{NO}_{2}$ will be completely consumed first during a fast $S C R$ reaction. Considering fast SCR reaction,

$2 \mathrm{NH}_{3}+\mathrm{NO}+\mathrm{NO}_{2} \rightarrow 2 \mathrm{~N}_{2}+3 \mathrm{H}_{2} \mathrm{O}$ we can write the number of moles of each species as

211 (according to $\mathrm{NH}_{3}: \mathrm{NO}: \mathrm{NO}_{2}$ ratio)

If the exhaust gas contains ' $\mathrm{x}$ ' mole $\mathrm{NO}_{2}$ if it is completely utilized, then the 2:1:1 ratio turns to $2 \mathrm{x}$ : $\mathrm{x}$ : $\mathrm{x}$ as given below. The consumption of NO during fast $S C R$ reaction is ' $\mathrm{x}$ ' mole.

$2 \mathrm{x} \quad \mathrm{x} \quad \mathrm{x}$

Remaining NO after fast SCR reaction= (Amount of NO before fast SCR reaction) -(Amount of NO consumed during fast $S C R$ reaction $)=(1-\mathrm{x})-\mathrm{x}=1-2 \mathrm{x}$ moles 


\section{RASĀYAN J. Chem.}

Vol. 14 | No. 4 |2486-2498| October- December | 2021

Assuming remaining $\mathrm{NO}$ of (1-2x) moles reacts with $\mathrm{NH}_{3}$ as per standard $S C R$ reaction (Eq.2) and writing the reaction and number of moles of reactant species we get,

$4 \mathrm{NH}_{3}+4 \mathrm{NO}+\mathrm{O}_{2} \rightarrow 4 \mathrm{~N}_{2}+6 \mathrm{H}_{2} \mathrm{O}$

$4 \quad 4 \div 4$ results

$1 \quad 1$

If $(1-2 \mathrm{x})$ moles of $\mathrm{NO}$ are utilized completely, then the molar proportion of $\mathrm{NH}_{3}$ : $\mathrm{NO}$ is $1-2 \mathrm{x} \quad 1-2 \mathrm{x}$

The $\mathrm{NH}_{3}$ required for 1 mole of $\mathrm{NO}_{\mathrm{x}}$ considering both fast and standard $S C R$ reactions is calculated as,

Total $\mathrm{NH}_{3}$ required $=\mathrm{NH}_{3}$ consumption during fast $S C R$ reaction $+\mathrm{NH}_{3}$ consumption during standard $S C R$ reaction $\Rightarrow 2 \mathrm{x}+1-2 \mathrm{x}=1$ mole.

According to this, 1 mole $\mathrm{NO}_{\mathrm{x}}$ requires 1 mole of $\mathrm{NH}_{3}$ for complete conversion of $\mathrm{NO}_{\mathrm{x}}$ if $\mathrm{NO}_{2} / \mathrm{NO}_{\mathrm{x}}$ ratio is less than 0.5 . In other words, $1 \mathrm{PPM}$ of $\mathrm{NO}_{\mathrm{x}}$ requires $1 \mathrm{PPM}$ of $\mathrm{NH}_{3}$ for complete conversion.

We know that if ' $\mathrm{x}$ ' is $\mathrm{NO}_{2} / \mathrm{NO}_{\mathrm{x}}$ ratio, 1 mole of $\mathrm{NO}_{\mathrm{x}}$ is equivalent to [(1-x) (30) +(x)46] g. Then, [(1-x)(30) $+(\mathrm{x}) 46] \mathrm{g} \mathrm{NO}_{\mathrm{x}}$ requires $-17 \mathrm{~g}$ of $\mathrm{NH}_{3}$

So, $\mathrm{NH}_{3}$ required for the conversion $1 \mathrm{~g}$ of $\mathrm{NO}_{\mathrm{x}}$ is $\frac{17}{(1-\mathrm{x}) 30+\mathrm{x} 46} \mathrm{~g}$

If the exhaust gas flow rate is $\mathrm{Mex}_{\mathrm{ex}}(\mathrm{kg} / \mathrm{hr})$ and if it contains $[\mathrm{X}] \mathrm{PPM}$ of $\mathrm{NO}_{\mathrm{x}}$, then the flow rate of $\mathrm{NO}_{\mathrm{x}}$ is obtained as $\mathrm{M}_{\mathrm{NOx}}=\frac{[\mathrm{X}]\{(1-\mathrm{x}) 30+\mathrm{x} 46\}}{29 \times 3600} \mathrm{M}_{\mathrm{ex}} 1000 \mathrm{~g} / \mathrm{sec}$ of $\mathrm{NO}_{\mathrm{x}} \quad$ (Appendix -Eq. (4))

Note: Constituents of exhaust gases can be taken as that of air as it contains other constituents in lesser percentages. So, the molecular weight 29 is considered for exhaust gases. If the mass flow rate of exhaust gas is $\mathrm{M}_{\mathrm{ex}}[\mathrm{kg} / \mathrm{hr}]$ and if it contains [X] PPM of $\mathrm{NO}_{\mathrm{x}}$ then, $\mathrm{NH}_{3}$ required is obtained as,

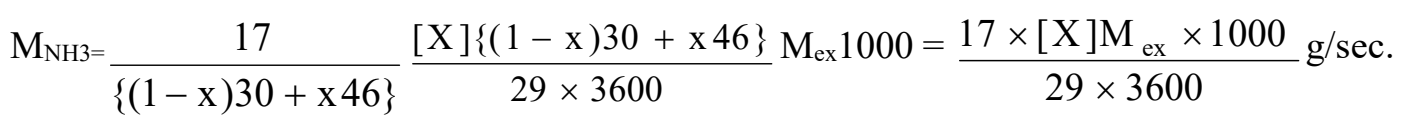

Case2: $\mathrm{NO}_{2} / \mathrm{NO}_{\mathrm{x}}>0.5$

When $\mathrm{NO}_{2} / \mathrm{NO}_{\mathrm{x}}>0.5$, then $\mathrm{NO}<\mathrm{NO}_{2}$, and it is assumed that $\mathrm{NO}$ is completely consumed first during fast $S C R$ reaction and remaining $\mathrm{NO}_{2}$ will take part in slow $S C R$ reaction. The maximum possible consumption of NO is ' $1-\mathrm{x}$ ' mole. So, we consider (1-x) moles of NO to take part in a fast SCR reaction. Considering fast $S C R$ reaction and writing the number of moles of reacting species we get,

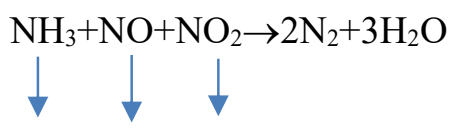

\section{$\begin{array}{lll}2 & 1 & 1\end{array}$}

for ' $1-\mathrm{x}$ ' moles of $\mathrm{NO}$, the ratio changes to

$2(1-\mathrm{x}) \quad 1-\mathrm{x} \quad 1-\mathrm{x}$

Remaining $\mathrm{NO}_{2}$ after fast $S C R$ reaction= (Amount of $\mathrm{NO}_{2}$ before fast $S C R$ reaction) $-\left(\right.$ Amount of $\mathrm{NO}_{2}$ consumed during fast $S C R$ reaction $)=\mathrm{x}-(1-\mathrm{x})=2 \mathrm{x}-1$. So, the $\mathrm{NH}_{3}$ required for one mole of $\mathrm{NO}_{\mathrm{x}}$ is $2 \mathrm{x}-1$ moles 


\section{RASĀYAN J. Chem.}

Vol. 14 | No. 4 |2486-2498| October- December | 2021

if a fast SCR reaction occurs. Considering slow SCR reaction and writing the number of moles of species we get,

$8 \mathrm{NH}_{3}+6 \mathrm{NO}_{2} \rightarrow 7 \mathrm{~N}_{2}+12 \mathrm{H}_{2} \mathrm{O}$

$8 \quad 6 \quad \div 6$

$8 / 6 \quad 1$

For $(2 \mathrm{x}-1)$ moles of $\mathrm{NO}_{2}$, the proportion becomes $4 / 3(2 \mathrm{x}-1)$ : $2 \mathrm{x}-1$

Total $\mathrm{NH}_{3}$ required $=\mathrm{NH}_{3}$ consumption during fast $S C R$ reaction $+\mathrm{NH}_{3}$ consumption during slow $S C R$ reaction.

For 1 mole $\mathrm{NO}_{\mathrm{x}}$, the total $\mathrm{NH}_{3}$ required is $2(1-\mathrm{x})+[4 / 3(2 \mathrm{x}-1)]$ mole $=\left\{\frac{2}{3}+\frac{2}{3} \mathrm{x}\right\}$ moles

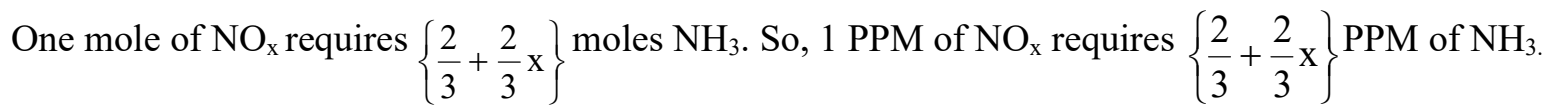

We know that 1 mole of $\mathrm{NO}_{\mathrm{x}}$ is equivalent to $[(1-\mathrm{x})(30)+(\mathrm{x}) 46] \mathrm{g}$.

So, (1-x) (30) $+(\mathrm{x}) 46 \mathrm{~g}$ of $\mathrm{NO}_{\mathrm{x}}$ requires $\left\{\frac{2}{3}+\frac{2}{3} \mathrm{x}\right\} \times 17 \mathrm{~g}$ of $\mathrm{NH}_{3}$

$1 \mathrm{~g}$ of $\mathrm{NO}_{\mathrm{x}}$ requires $\frac{\left\{\frac{2}{3}+\frac{2}{3} \mathrm{x}\right\} 17}{(1-\mathrm{x}) 30+\mathrm{x} 46} \mathrm{~g}$ of $\mathrm{NH}_{3}$

If the exhaust gas contains [X] PPM of $\mathrm{NO}_{x}$, then $\mathrm{NH}_{3}$ required will be $\left\{\frac{2}{3}+\frac{2}{3} \mathrm{x}\right\}[\mathrm{X}] \mathrm{PPM}$

As mentioned earlier, if the exhaust gas flow rate is $\mathrm{M}_{\mathrm{ex}} \mathrm{kg} / \mathrm{hr}$ and if it contains $[\mathrm{X}] \mathrm{PPM}$ of $\mathrm{NO}_{\mathrm{x}}$, then the flow rate of $\mathrm{NO}_{\mathrm{x}}$ is obtained as,

$\mathrm{M}_{\mathrm{NOx}}=\frac{[\mathrm{X}]\{(1-\mathrm{x}) 30+\mathrm{x} 46\}}{29 \times 3600} \mathrm{M}_{\mathrm{ex}} \times 1000 \mathrm{~g} / \mathrm{sec}$ of $\mathrm{NO}_{\mathrm{x}}$

(Appendix-Eq. (4))

$\mathrm{NH}_{3}$ requirement for the above mass flow rate of $\mathrm{NO}_{\mathrm{x}}$ is obtained as,

$\mathrm{M}_{\mathrm{NH} 3}=\frac{\left\{\frac{2}{3}+\frac{2}{3} \mathrm{x}\right\} 17}{\{(1-\mathrm{x}) 30+\mathrm{x} 46\}} \frac{[\mathrm{X}]\{(1-\mathrm{x}) 30+\mathrm{x} 46\}}{29 \times 3600} \mathrm{M}_{\mathrm{ex}} 1000=\left\{\frac{2}{3}+\frac{2}{3} \mathrm{X}\right\} \frac{17 \times[\mathrm{X}] \mathrm{M}_{\mathrm{ex}} \times 1000}{29 \times 3600}$

In general, we can write,

$$
\begin{aligned}
\mathrm{M}_{\mathrm{NH} 3}=\mathrm{K} \frac{17 \times[\mathrm{X}] \mathrm{M}_{\mathrm{ex}} \times 1000}{29 \times 3600} & \\
\text { where } & \text { (i) } \mathrm{K}=1 \text { if } \mathrm{NO}_{2} / \mathrm{NO}_{\mathrm{x}}<0.5 \\
& \text { (ii) } \mathrm{K}=\left\{\frac{2}{3}+\frac{2}{3} \mathrm{x}\right\} \text { if } \mathrm{NO}_{2} / \mathrm{NO}_{\mathrm{x}}>0.5
\end{aligned}
$$

\section{REFERENCES}

1. M. Koebel, E. O. Strutz, Industrial \& Engineering Chemistry Research, 42(10), 2093(2003), https://doi.org/10.1021/ie020950o

2. M. Koebel, Martin Elsener and M. Kleemann, Catalysis Today, 59(3-4), 335(2000), https://doi.org/10.1016/S0920-5861(00)00299-6

3. D. S. Yim, S. J. Kim, J. H. Bai, K. I. Nam, Y. S. Mok, J. W.Lee, B. K. Cho, S. H. Oh, Industrial \& Engineering Chemistry Research, 43(16), 4856(2004), https://doi.org/10.1021/ie034052j

4. M. Calatayud, B. Mguig and C. Minot, Surface Science Reports, 55(6-8), 169(2004), 


\section{RASĀYAN $J$. Chem.}

Vol. 14 | No. 4 |2486-2498| October- December | 2021

https://doi.org/10.1016/j.surfrep.2004.05.002

5. C. Ciardell, Applied Catalysis B: Environmental, $\quad \mathbf{7 0 ( 1 - 4 ) ,} \quad 80(2007)$ https://doi.org/10.1016/j.apcatb.2005.10.041

6. H. Tao, (2009) Ph.D. Dissertation, Wuhan University of Technology, China.

7. L. Lü and L. Wang, International Journal of Automotive Technology, 14(1), 13(2013), https://doi.org/10.1007/s12239-013-0002-6

8. M. Koebel, M. Elsener, G. Madia, Industrial \& Engineering Chemistry Research, 40, 52(2001), https://doi.org/10.1021/ie000551y

9. Sébastien Grout, Jean-Bernard Blaisot, Karine Pajot, Giovanni Osbat. Fuel, 106, 166(2013), https://doi.org/10.1016/j.fuel.2012.09.022

10. F. Birkhold, U. Meingast, P. Wassermann, and O. Deutschmann, Applied Catalysis B: Environmental, 70,119(2007), https://doi.org/10.1016/j.apcatb.2005.12.035

11. R. Rota, D. Antos, E. F. Zanoelo and M. Morbidelli, Chemical Engineering Science, 57, 27(2002), https://doi.org/10.1016/S0009-2509(01)00367-0

12. H. Aoki, T. Fujiwara, Y. Morozumi, and M. Takatoshi, Measurement of urea thermal decomposition reaction rate for NO selective non-catalytic reduction, in Proceedings of the Fifth International Conference on Technologies and Combustion for a Clean Environment, pp. 115-118, Lisbon, Portugal, 1999.

13. J.Y.Kim, S.H.Ryu, J.S.Ha, Numerical prediction on the characteristics of spray-indused mixing and thermal decomposition of urea solution in SCR system, in: Proc.2004 Fall Technical Conference of the ASME Internal Combustion Engine Division, Long Beach. ICEF2004-0889 https://doi.org/10.1115/ICEF2004-0889

14. Jakov Baleta, Hrvoje Mikulcic, Milan Vujanovic, Zvonimir Petranovic, Neven Duic Numerical simulation of urea based selective non-catalytic reduction deNO $\mathrm{N}_{\mathrm{x}}$ process for industrial applications. Energy Conversion and Management, 125, 59(2016), https://doi.org/10.1016/j.enconman.2016.01.062

[RJC-6427/2021] 